\title{
Developing and Testing the Validity of Career Readiness-Personality (CR-P) Module for University Students
}

\author{
Nik Rafidah Nik Yusoff, Mastura Mahfar, Muhammad Sukri Saud
}

\begin{abstract}
Career readiness and personality are the two main important aspects that need to enhance among the university students. Thus, the Career Readiness-Personality (CR-P) Module was developed as an intervention aim to increase the students' career readiness and enhance their personality. The Career Readiness-Personality (CR-P) Module was developed based on The Social Career Cognitive Theory (SCCT) and Big Five Personality Model. The Social Career Cognitive Theory (SCCT) was introduced by Albert Bandura (1986) and Big Five Personality Model by McCrae \& Costa (1987). This research aims to develop the CR-P Module and to determine the content validity of the CR-P Module for university students. The development of CR-P Module was based on the two sub modules known as Career Self-Efficacy and Big Five Personality. After the module development, the content validity of the module was evaluated by eight experts and the research findings showed that the value of content validity coefficient was 0.92 . In conclusion, this research indicated that the CR-P Module has a high validity which can be utilized by university students.
\end{abstract}

Keywords: Big Five Personality Model, Career Readiness-Personality (CR-P) Module, career self-efficacy, content validity, developing.

\section{INTRODUCTION}

Career readiness and personality are found to be the two essentials aspects for individual to be employed. The university students however are found to be lacking in both aspects. This has caused Malaysian government to be concerned about the career readiness and personality development of university students. Among the initiatives done by the Malaysian government are the Malaysia Education Blueprint 2015-2025 (Higher Education) (1), the Eleventh Malaysia Plan (2) and The National Graduate Employability Blueprint 2012-2017 (3).

Malaysia Education Development Plan 2015-2025 (Higher Education) emphasizes on the development of graduates with holistic, entrepreneurial and balanced characteristics (1)(Ministry of Education, 2015). While one

Revised Manuscript Received on October15, 2019

Nik Rafidah binti Nik Yusoff*, Azman Hashim International Business School, Universiti Teknologi Malaysia, Johor Bahru, Johor, Malaysia. nikrafidah@utm.my

Mastura binti Mahfar, Faculty of Social Sciences and Humanities, Universiti Teknologi Malaysia, Johor Bahru, Johor, Malaysia. mastura@management.utm.my

Muhammad Sukri bin Saud, Faculty of Social Sciences and Humanities, Universiti Teknologi Malaysia, Johor Bahru, Johor, Malaysia. p-sukri@utm.my of the core strategies in the Eleventh Malaysia Plan is to enhance human capital development for developed countries which is an important factor in providing a highly skilled workforce (2). The Ministry of Higher Education as well has introduced 'The National Graduate Employability Blueprint 2012-2017' aimed at strengthening graduates' talent in professional and skilled fields (3). 'The National Graduate Employability' emphasizes on the readiness of students before going into the field of employment and the personality of students through the Generic Students Attribute 2017 (3). In addition, feedback of industrial companies at one of the universities in Malaysia has shown that university students lack of career readiness and the personality development (4). This clearly shows that the career readiness and personality development are greatly emphasized by the Malaysian government and industrial companies as well.

Career self-efficacy has five dimensions, namely self-appraisal, occupational information, goal selection, planning, and problem solving (5-7). High-level self-efficacy reflects that individuals will have high self-esteem in completing their job duties and will positively influence career exploration in the future as well as in career decision-making (8).

In addition to the self-efficacy of the career, the personality aspect is also an important variable to assist in the students' career development. In this study, the Big Five Personality model was selected to examine the personality aspect of the students. The Big Five Personality Model divides the individual personality into five personality traits, namely openness to experience, conscientiousness, extraversion, agreeableness and neuroticism (9-12) Rogers, Creed \& Glendon (2008) conducted a study to examine the role of personality for career planning and exploration among teenagers using the Social Cognitive Career Theory. The results of the study show that personality aspect has a linear relationship with the career selection process (13).

\section{PROBLEM STATEMENT}

Based on the percentage of graduates' employability in public universities, the percentage of unemployed graduates after graduation from 2013 to 2015 was $30.1 \%$ (14). This percentage shows that the percentage of graduates in Malaysia who earned post-employment employment was $69.9 \%$ and this percentage had not yet reached the target set by the Ministry of Higher Education, which is $80 \%$. (14). 


\section{Developing and Testing the Validity of Career Readiness-Personality (CR-P) Module for University Students}

According to Zaini Ujang (2009), the university should be able to produce graduates who are acceptable in terms of knowledge and skills by the job market, thus creating new job opportunities (15).

A study conducted by Zalizan Mohd Jelas et al (2013) found that university students only attain a moderate level of career self-efficacy and require more guidance(16). Besides that, the Ministry of Education Malaysia (2015) (14) stated that several employers provide feedback that some graduates are lacking in terms of knowledge, skills and attitudes which contribute to their career readiness.

Personality is also another aspect highlighted in this study. Based on the content of the speech done by Minister of Higher Education in 2012 at the National Graduate Employability Blueprint 2012-2017 Personality Launch event, personality is one of the aspects that should be emphasized by university students to assist them in the career readiness and thus facilitate them to be offered a job (3). Not only that, the career self-efficacy and personality are among the key aspects of students' career readiness (17-19).

However, the National Graduate Employability Blueprint Report 2012-2017 (20) found that the most frequent issue identified by employers was the personality of graduates that need to be improved (37.4\%). In fact, according to Norasikin Che Rani (2012) (21), there is only few studies done on the topic of personality among graduates in local universities.

\section{LITERATURE REVIEW}

\section{A. Career Self-Efficacy}

Career self-efficacy refers to the individual's ability to make judgments, organize and implement the desired actions to achieve the desired career goals based on the particular skills they possess (16). Besides that, career self-efficacy is also closely linked to individual perceptions on self-control that will help one to deal with problems in an environment (22).

Among the studies done related to career self-efficacy are self-efficacy in career decision making (Gianakos, 2001), career planning and exploration (13) and career choices $(23,24)$. Furthermore, career self-efficacy can also help to alleviate problems related to a career decision (25).

\section{B. Big Five Personality Model}

According to Larsen and Buss (2017), personality is a set of stable and lasting mechanisms and psychological features within individuals that can be categorized into groups based on the quality of an individual. Personality is also a psychophysical system to create individuals with dynamic thinking, feelings and attitudes based on their personality traits, due to the consistent-trait based internal characteristics (26).

The Big Five Personality Model is divided into five dimensions namely openness to experience, conscientiousness, extraversion, agreeableness and neuroticism. Among the meaning of openness to experience is curious $(10,27,28)$. Whereas according to Borgatta, (1964) (29), John, (1990)(30) and Goldberg, (1981) (31), the meaning of openness to experience is intellect. In addition, among the meaning of conscientiousness is a systematic $(10,32,33)$, and task-oriented individual $(34,35)$.

As for the extraversion meaning, among them is love to communicate $(27,28,32)$, socialize (27) and interact with other people $(34,36)$ (Hogan, 1986; John et al, 2008). On the other hand, the meaning of agreeableness is cooperative $(27,32,37)$, polite $(10,27,37)$ generous and forgiving $(10,27)$. The meaning of neuroticism is those who have the following characteristics of stress, worry, unstable, uncertain, fear, nervous, depressed, lacking of rest, emotional and unsafe (27), while according to Hee (2014), the meaning of neuroticism is depressed, slightly disheartened and grumpy.

\section{The Career Readiness-Personality Module}

The researchers chose the Sidek Module Development Model (Sidek Mohd Noah \& Jamaludin Ahmad, 2005) for the development of the Career Readiness-Personality Module which was introduced by Sidek Mohd Noah in 2001. This model is an integrated model and more comprehensive in module development (38). This model has two distinct stages, the first stage is the stage of preparing the draft module while the second is the stage of testing and evaluating the module (38). Figure 1 presents the process of module development as suggested by Sidek Mohd Noah \& Jamaludin Ahmad (2005).

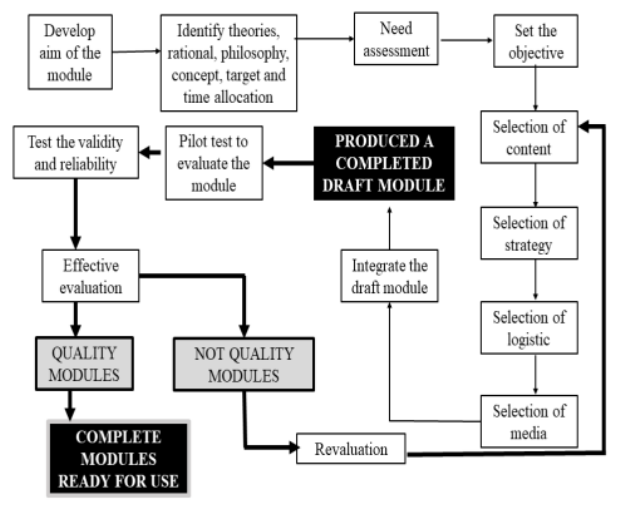

Fig. 1. Sidek's Module Development Model (Source: Noah \& Ahmad, 2005)

The CR-P module has two sub modules, namely the Career Self Efficacy and Big Five Personality. The total of the activities are 30 activities. The career self-efficacy sub module is built based on the five dimensions $(39,40)$, namely: self-appraisal, occupational information, goal selection, planning and problem solving. While for the Big Five Personality sub module, it is built based on the five traits which are openness to experience, conscientiousness, extraversion, agreeableness and neuroticism.

The uniqueness of CR-P module is built specifically as an intervention to university students who face career readiness issues in terms of career self-efficacy. Apart from that, the CR-P Module is also built to shape their personality. The activities integrated in the module are developed based on the Social Cognitive Career Theory $(6,41)$ and Big Five Personality Model (42).

In addition, the strengths for this module is there are several elements that are included in these activities such as graphics, audios and visuals to attract the students' interest and gain their attention while participating in the activities. The activities in this module include drills, simulations, short talks, games, individual and group assignments, discussions and presentations.




The selection of game activity is aimed at encouraging learning while having fun (43).

Not only that, the CR-P Module also integrates information technology elements in which online games such as Kahoot and Mentimeter are used as one of the media selections in module activities. Media selection should be taken into account in order to attract, motivate and encourage participants to use the module (38)(Jamaludin Ahmad \& Sidek Mohd Noah, 2005). In fact, game activity is also added to create excitement to students' learning (43).

The following as stated in Figure 2 dan Figure 3 were the content of the Career Readiness-Personality Module:

\section{The Career Readiness-Personality (CR-P) Module}

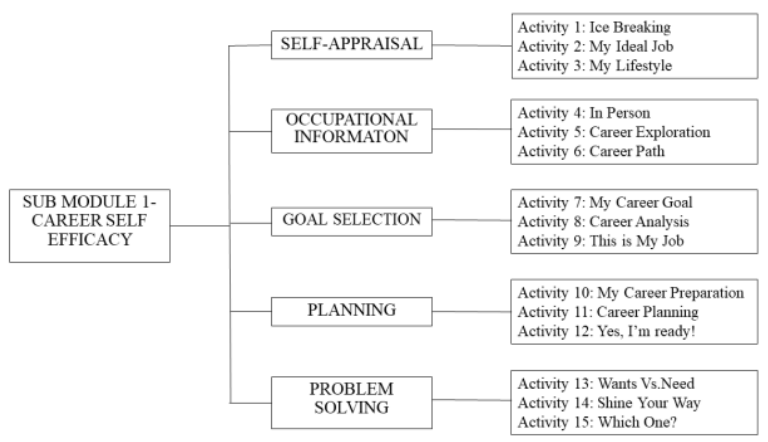

Fig. 2: Summary of the activities in the Sub Module 1Career Self-Efficacy

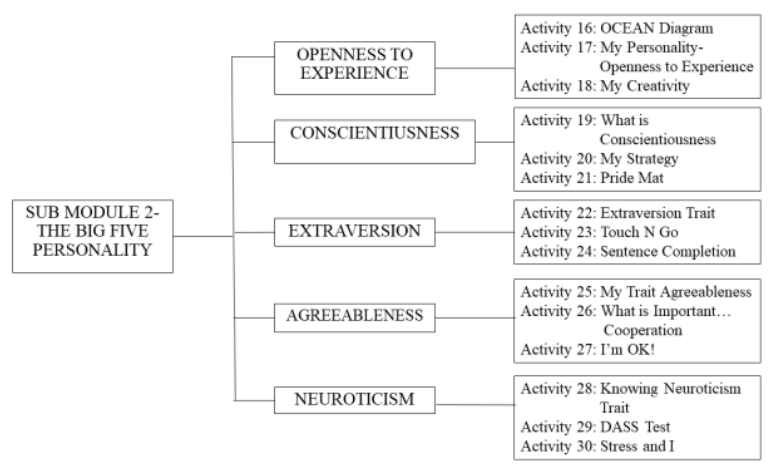

Fig. 3: Summary of the activities in the Sub Module 2The Big Five Personality

\section{E. Research Objectives}

The main objective of this study is to develop Career Readiness-Personality Module for university students that has a high validity. Hence, the objectives are:

(i) to develop the Career Readiness-Personality Module for university students.

(ii) to determine the content validity of the Career Readiness Module for university students.

\section{RESEARCH METHODOLOGY}

This study uses descriptive study design. To measure the validity of the module content, eight experts had been appointed to evaluate the content of the Career- Readiness Personality Module. Specifically, six experts with Doctor of Philosophy in counseling and psychology who are also experts in the development of modules at several universities in Malaysia. Besides that, another two psychologists who hold a Ph.D in counseling and psychology and has over 10 years of experience as psychologists at public universities in Malaysia had been appointed as module assessors.

The researchers had referred the content validity of the questionnaire developed by Jamaludin Ahmad (2002) based on the observation of the validity requirements of the module developed by Russell (1974). The questionnaire consists of five questions which use the five-point Likert scale from the Strongly Agreeable scale (5) to the Very Disagree $(0)$. The questionnaire was given to the designated content experts to respond (38). Previous researchers were found to use the same procedure to analyze the validity of the module content and the validity was proven high (44-50).

In calculating the validity of the module content, the study uses the formula-based module validity calculation method suggested by Sidek Mohd Noah and Jamaludin Ahmad (2005) based on Russelll (1974). The number of scores awarded by experts through Likert scale $(\mathrm{X})$ is divided by the maximum score of Likert scale (25) and then multiply by 100 percent. Sidek Mohd Noah and Jamaludin (2005) believe that the determination of good content should be based on the suggestion made by Tuckman and Waheed (1981)(51) and Abu Bakar Nordin (1995)(52). According to Tuckman and Waheed (1981)(51) and Abu Bakar Nordin (1995)(52), a module content that reaches 70 percent is considered to have a good content validity. Hence, if a module gets a score of 70 percent and above, then the module has a good content validity and vice versa.

\section{FINDINGS AND DISCUSSION}

The content validity of this module is based on Russell (1974) (53). The five items were evaluated by eight experts. The results from the assessment done by the eight experts found that the content validity of the Career-Personality Ready Module was 0.92 which exceeds the minimum level of 0.70 . For each category as well, the validity rating of the content was between 0.85 and 0.98 that stated in Table 1. This indicates that the content validity of the Career-Personality Ready Module is high as recommended by Sidek Mohd Noah and Jamaludin (2005) (38), Tuckman and Waheed (1981) (51) and Abu Bakr Nordin (1995) (52). The value shows a good content validity. Also, this value indicates that the CR-P module can measure what is within its scope.

Table I: The value of content validity for Career Readiness-Personality Module (CR-P)

\begin{tabular}{|l|l|l|l|}
\hline NO. & STATEMENT Percentage & Validity \\
\hline $\mathbf{1 .}$ & $\begin{array}{l}\text { The content of the Career } \\
\text { Readiness-Personality (CR-P) } \\
\text { Module meets its target } \\
\text { population. }\end{array}$ & $93 \%$ & 0.93 \\
\hline $\mathbf{2 .}$ & $\begin{array}{l}\text { The content of the Career } \\
\text { Readiness-Personality (CR-P) } \\
\text { Module can be successfully } \\
\text { implemented. }\end{array}$ & 0.93 \\
\hline 3. & $\begin{array}{l}\text { The content of the Career } \\
\text { Readiness-Personality (CR-P) } \\
\text { Module is suitable with the time } \\
\text { allocated. }\end{array}$ & $\begin{array}{l}\text { (\%) } \\
\text { The content of the Career } \\
\text { Readiness-Personality (CR-P) } \\
\text { Module can help students to } \\
\text { improve their career } \\
\text { self-efficacy. }\end{array}$ & 0.85 \\
\hline
\end{tabular}




\section{Developing and Testing the Validity of Career Readiness-Personality (CR-P) Module for University}

Students

\begin{tabular}{|l|l|l|l|}
\hline $\mathbf{5 .}$ & $\begin{array}{l}\text { The content of the Career } \\
\text { Readiness-Personality (CR-P) } \\
\text { Module can help students to } \\
\text { develop their personality. }\end{array}$ & 0.93 \\
\hline Overall & $\mathbf{9 2 \%}$ & $\mathbf{0 . 9 2}$ \\
\hline
\end{tabular}

\section{IMPLICATIONS AND SUGGESTIONS}

This study is greatly hope will benefit and contribute to those involved in university students' career development. The results of this study are greatly hope to contribute in terms of knowledge development of modules relating to career readiness and personality among university students emphasizing on the two main aspects, namely the students' self-efficacy and personality.

Furthermore, this study manages to develop a Career Readiness-Personality Module with a high level of validity by combining both important aspects of career readiness, namely career self-efficacy and the Big Five personality. Therefore, it is hoped that this module can be used as a guide and useful reference to those involved in the development of UTM students' careers, especially the psychologists at the universities.

Moreover, until now, there is still no Career-Readiness Personality Module that has actually undergone a scientific research process. This module can be used as part of the career programs that will be carried out by the psychologists at the universities. As it is proven to have a high content validity, it is expected to be useful for psychologists particularly who are responsible for the university students' careers.

It is hoped that the CR-P module will enhance career readiness among university students and assist university students develop a good personality for their future careers.

\section{CONCLUSION}

In conclusion, this study has developed a Career-Readiness Personality Module based on Sidek Module Development Model with high value in validity (36.) Therefore, this module is to be used for reliability testing and further experimental studies to test its effectiveness on university students. This module is expected to contribute a good effect to the university students in order to enhance the career self-efficacy and personality for career readiness after accomplished their studies in the university.

\section{REFERENCES}

1. Ministry of Education. Malaysia Education Development Plan. Putrajaya; 2015.

2. Department of Prime Minister. The Eleventh Malaysia Plan. Putrajaya; 2015.

3. Ministry of Higher Education. Tracer Study Research Report 2011. Putrajaya; 2012.

4. UTM Career Centre. Testimonial Report From Industries. UTM Johor Bahru; 2014.

5. Bandura A. Social foundations of thought and action: A social cognitive theory. Englewood Cliffs, NJ: Prentice Hall, Inc; 1986.

6. Lent, Robert W., S.D. Brown GH. Career development from a social cognitive perspective. In: Career Choice and Development. San Francisco, CA: Jossey-Bas; 1996.

7. Lent RW, Brown SD, Hackett G. Social Cognitive Career Theory. In: Career Choice and Development [Internet]. 2002. p. 255-560.

8. Betz NE, Voyten KK. Efficacy and Outcome Expectations Influence Career Exploration and Decidedness. Career Dev Q [Internet]. 1997;46(December 1997):179-89.

9. Goldberg LR. The Structure of Phenotypic Personality Traits. Am Psychol Assoc. 1993;48(1):26-34.
10. John OP, Srivastava S. The Big Five trait taxonomy: History, measurement and theoritical perspectives. In: Handbook of personality: Theory and research. New York: The Guildford Press; 1999.

11. Gosling SD, Rentfrow PJ, Swann WB. A very brief measure of the Big-Five personality domains. J Res Pers. 2003;37:504-28.

12. Engler B. Personality Thoeries-eight edition. Boston: Houghton Mifflin Harcout Publishing Company; 2009.

13. Rogers ME, Creed PA, Glendon AI. The role of personality in adolescent career planning and exploration: A social cognitive perspective. J Vocat Behav. 2008;73:132-42.

14. Ministry of Higher Education. Tracer Study Research Report 2015. Putrajaya; 2016.

15. Ujang $Z$. The elevation of higher learning (Mengangkasa Pengajian Tinggi). UTM Johor Bahru: Universiti Teknologi Malaysia Press; 2009.

16. Mohd Jelas Z, Mohd Salleh A, Azman N, Hamzah R, Jani R, Hamzah H, et al. Research Report: Gender Analysis in Education. 2013.

17. Norman H, Zainon R, Md Jenil SZ, Yahya R. Graduates personality that attracs organization. $\mathrm{J}$ Bus Innov. 2017;2(1):53-61.

18. Makhbul ZM, Yussof I, Awang AH. Analysis of employers' perceptions of higher education graduates. In: National Social Science Conference 2011. Kuching: Universiti Malaysia Sarawak; 2011. p. 1-12.

19. Esa A, Hassan A. I'm sure I can! In: UTM Press, editor. Reaching for the star. Skudai; 2013.

20. Ministry of Higher Education. The National Graduate Employability Blueprint 2012-2017. Ministry of Higher Education. Putrajaya; 2012.

21. Rani NC. Personaliti Big Five, self-esteem and career selection decision among universiti students. Universiti Teknologi Malaysia; 2012.

22. Chiesa R, Massei F, Guglielmi D. Career Decision-Making Self-Efficacy Change in Italian High School Students Boosting Career Exploration: J Couns Dev. 2016;94:210-25.

23. Jin L, Watkins D, Yuen M. Personality, career decision self-efficacy and commitment to the career choices process among Chinese graduate students. J Vocat Behav [Internet]. 2009;74:47-52.

24. Wang N, M.Jome L, Haase RF, Bruch MA. The Role of Personality and Career Decision-Making Self-Efficacy in the Career. J Career Assess. 2006;14(3):312-32.

25. Fouad N, Cotter EW, Kantamneni N. The Effectiveness of a Career Decision-Making Course. J Career Assess. 2009; 17(3):338-47.

26. C.S C, Scheier M. Perspective of personality. United States of America: John Wiley \& Sons; 2000.

27. Barrick MR, Mount MK. The Big Five Personality Dimensions and Job Performance: A Meta-Analysis. Pers Psychol. 1991;44:1-26.

28. Hee OC. Validity and Reliability of the Big Five Personality Traits Scale in Malaysia. Int J Innov Appl Stud. 2014;5(4):309-15.

29. Borgatta EF. The Structure of Personality Characteristics. 1964;8-17.

30. Digman JM. Personality Structure: Emergence Of The Five-Factor. Annu Rev Psychol. 1990;41:417-40.

31. Goldberg L. Language and individual differences: The search for universals in personality lexicons. In: LWheeler (Ed), Review of personality and social psychology. Beverly Hills, CA: SAGE; 1981. p. 141-65.

32. Norman WT. Toward an adequate taxonomy of personality attributes: Replicated factor structure in peer nomination personality ratings. J Abnorm Soc Psychol. 1963;66(6):574-83.

33. Barrick MR, Mount MK. Autonomy as a Moderator of the Relationships Between the Big Five Personality Dimensions and Job Performance. J Appl Psychol. 1993;78(1):111-8.

34. John OP, Naumann LP, Soto CJ. Paradigm shift to the integrative Big Five Trait taxonomy. In: Handbook of personality: Theory and

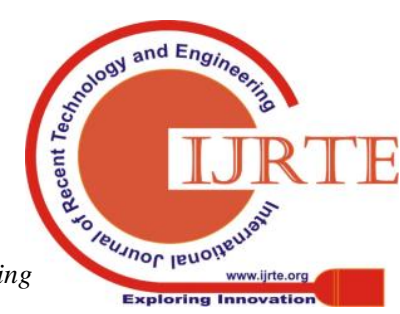


research. 2008.

35. Deneve KM, Copper H. The Happy Personality : A Meta-Analysis of 137 Personality Traits and Subjective Well-Being. Psychol Bull. 1998;124(2):197-229.

36. Hogan R. Hogan Personality Inventory manual. Minneapolis:MN: National Computer Systems; 1986.

37. Mccrae RR, Costa PT. Personality Trait Structure as a Human Universal. Am Psychol. 1997;52(5):509-16.

38. Noah SM, Ahmad J. Module development: How to develop training modules and academic modules. Serdang : Universiti Putra Malaysia Press; 2005.

39. Betz NE, Klein KL, Taylor KM. Evaluation of Short Form of the Career Decision-Making. J Career Assess. 1996;4(1):47-57.

40. Betz NE, Luzzo DA. Decision-Making Self-Efficacy Scale. 1996;413-28.

41. Bandura A. Self-efficacy: the exercise of control. New York: Freeman and Company; 1997.

42. McCrae RR, Costa PT. Validation of the five-factor model of personality across instruments and observers. J Pers Soc Psychol [Internet]. 1987;52(1):81-90.

43. Ahmad J. Self-motivation module. Kuala Lumpur: Dewan Bahasa dan Pustaka; 2015.

44. Mahmud MI. The effects of the Cognitive Information Processing Psycho-Education Career Program on the Dysfunctional Career Thoughts and Career Self-Efficacy of public university students. (Unpublished doctoral thesis). Universiti Putra Malaysia; 2017.

45. Abdul Jalil NI. Effects of rational emotive behavioural therapy module on irrational beliefs and job stress among university support staff. Universiti Teknologi Malaysia; 2017.

46. Jasmi Abu Talib. The effects of career exploration modules on career planning skills, career self-efficacy and career maturity among community college students. (Unpublished doctoral thesis). Universiti Kebangsaan Malaysia; 2014.

47. Mahfar M, Noah SM, Senin AA. Development of Rational Emotive Education Module for Stress Intervention of Malaysian Boarding School Students. SAGE Open. 2019;(2):1-16.

48. Jaamat MA. Applying Ericson, Piaget and Super Theory in he development of Career Awareness Modules for Malaysian secondary school students. (Unpublished doctoral thesis). Universiti Putra Malaysia; 2010.

49. Abdul Hanid Halit. The effects of career program on career development level among secondary school students in Dungun district, Terengganu, Malaysia. (Unpublished doctoral thesis). Universiti Putra Malaysia; 2007.

50. Ahmad J. The validity, reliability and effectiveness of the self-developed module on achievement motivation among secondary school students in Selangor (Unpublished doctoral thesis). Universiti Putra Malaysia; 2002.

51. Tuckman BW, Waheed MA. Evaluating an individualized science program for community college students. J Res Sci Teach. 1981;18(6):489-95.

52. Abu Bakar Nordin. Affective assessment. Kajang: Masa Enterprise; 1995.

53. Russell J. Modular instruction: A guide to the design, selection, utilization and evaluation of modular materials. United States of America: Publishing Company; 1974.

\section{AUTHORS PROFILE}

Nik Rafidah is presently a $\mathrm{PhD}$ candidate in the Universiti Teknologi Malaysia (UTM). She has completed her Master and Bachelor Degree in Guidance and Counseling in education, Universiti Teknologi Malaysia. She actively involved in career counseling activities and programs at Universiti Teknologi Malaysia.

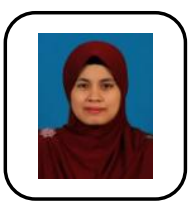

Dr Mastura Mahfar is a senior lecturer in counselling in the School of Human Resource Development and Psychology at Universiti Teknologi Malaysia. She holds a $\mathrm{PhD}$ in Guidance and Counselling from Universiti Putra Malaysia. Her research interest includes stress intervention and workplace counselling. She teaches counselling and psychology courses and supervises master and doctoral projects within these fields.

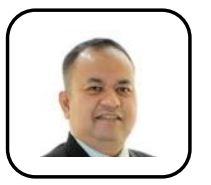

Professor Dr Muhammad Sukri Saud is currently working in the Department of Technical and Engineering, School of Education, Faculty of Human Sciences and Humanities, Universiti Teknologi Malaysia. He completed his $\mathrm{PhD}$ in Human Resource and Community Development from the Ohio State university, USA. He is actively involved in research on career and talent development of students and the community. $\mathrm{He}$ has given numerous presentations, organized meeting, performed research and authored numerous peer-reviewed articles in Career and Technical education (CTE). He is actively involved in supervising $\mathrm{PhD}$ and Master students. 